\title{
WOMEN AT THE STOUT CENTRE
}

The Victoria University Federation of Women, with assistance from the 1990 Commission, mounted a historical display titled 'Women at Victoria' at various venues within the University during August 1990. Accounts of women who have been resident at the Stout Research Centre were included, and document the deeply appreciated role played by the Stout in advancing the work of women researchers. Brief biographical profiles are prresented here.

Wendy Pond

Jane Tolerton

Judith Binney was the J.D. Stout Fellow for 1985, and wrote there $N g \bar{a}$ Mörehu: The Survivors, an oral history of 8 Māori women associated, in their different ways, with the Rangatū faith. This work was published in 1986, won the third prize in the Wattie Book Awards in 1987, and has been reprinted twice. Since then she has published further articles and in 1990, (with Judith Bassett \& Erik Olssen) Te tangata me te Whenua: The People and The Land, An Illustrated History of N.Z, 1820-1920, which is a new community-based history.

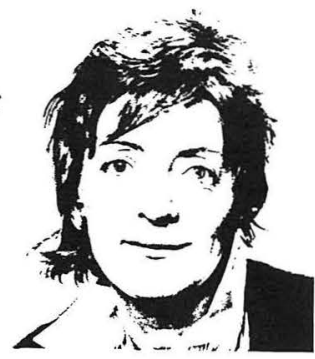

Winifred Bauer is the J.D. Stout Fellow for 1990. She is working on a more comprehensive reference grammar of Maori with the assistance of a Maori woman consultant Tekareongawai Evans of Te Aopouri. She has published a number of articles in international journals on aspects of the structure of Maori, and her $\mathrm{PhD}$ thesis, the material from which is incorporated into the present project, is still in considerable demand by linguists world-wide. She was a Junior Lecturer at the ELI at Victoria for four years, has tutored in the Linguistics Department at Victoria almost every year since 1979, and for three years, taught a course for the Maori Studies Department.

Shirley Day (formerly Gieck) worked in an administration role with Volunteer Service Abroad before leaving to study for a BA, majoring in Sociology, at Victoria University. While completing her degree, Shirley was Secretary at the Stout Centre, working with Jock Phillips to set up the new centre. Shirley is now employed as Executive Assistant at the National Art Gallery and Museum.

Anne Else is a freelance feminist writer, researcher, lecturer, broadcaster and editor. She spent 1988 and half of 1989 at the Stout Centre as the Claude McCarthy Fellow, writing $A$ Question of Adoption, a book about closed stranger adoption in post-war NZ, to be published in 1991. Recent publications include papers on adoption in the International Journal of the Sociology of Law and the New Zealand Journal of History. Her other research interests include women's biography and autobiography; with an earlier Stout resident, Heather Roberts, she coedited A Woman's LIfe, an anthology of writing by women about female experience in NZ, published by Penguin in 1989. She is also the editor of the Women's Studies Journal. In 1990 she was awarded Victoria's Sarah Anne Rhodes Fellowship to undertake a PhD in history, examining the state's involvement in adoption.

Judith Fyfe, Executive Director of the New Zealand Oral History Archive, spent two years at the Stout Centre, 1984-1985. During this time she carried out Archive work and co-produced The Gamble: The Campaign Diary of the Challengers, an oral history of the 1984 snap General Election, the first book to come out of the Stout Centre. Her background is in radio and television as journalist and actor. She has written many television drama scripts and is the author of The Matriarchs, published in 1990 by Penguin.

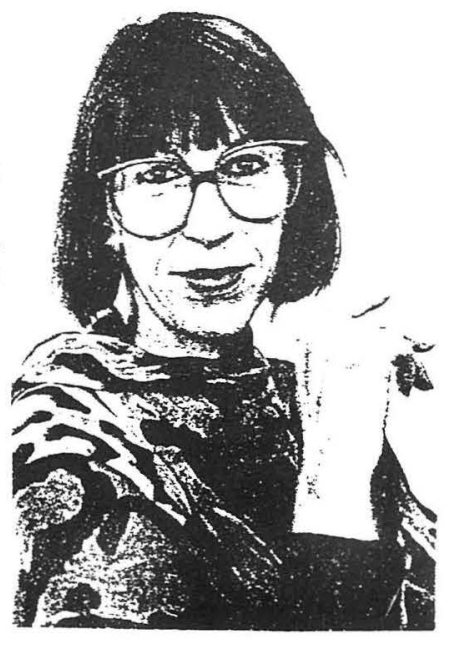


Julie Glamuzina, who was resident at the Stout Centre in 1987 is a lesbian feminist of Yugoslav descent. While resident she undertook research on the significance of the Parker-Hulme murder case of 1954 with Alison Laurie. She has recently completed a booklet The Herstory of Lesbian Politics in Aotearoa, 1962 - 1985. She is a contributor to the Dictionary of New Zealand Biography. Currently she is a tutor at Waikato Polytechnic.

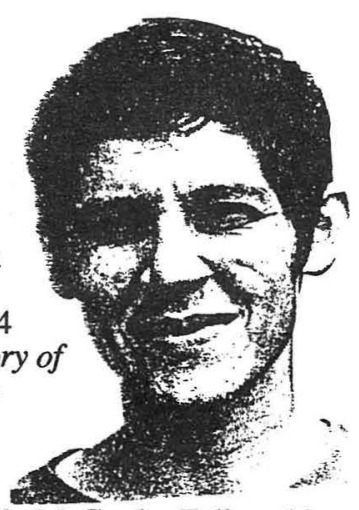

Alison Gray was at the Stout Centre in 1987 as the holder of a Claude McCarthy Fellowship to research the attitudes and experiences of New Zealand teenagers. The results were published by Allen \& Unwin in 1988 as Teenagers - being a New Zealand Teenager. Her other publications include The Smith Women. The Jones Men, Expressions of Sexuality, The Marriage Maze, and Stepping Out. She is currently working on a book about women who take on a new challenge in mid life, and a third novel.

Jean Harton was at the Stout Centre during 1984-1985 with the New Zealand Oral History Archive, then in its early stages of development. During this time she worked on various Archive activities including The Gamble: The Campaign Diary of the Challengers, an oral history of the 1984 snap General Election. Her background is in television where she worked on many programmes as Producer's Assistant. As Administrator of the NZOHA, she is responsible for its general organisation and co-ordination as well as all post-interview project work.

Valerie Jacobs has been the Secretary at the Stout Centre since 1986. She was the Wellington Provincial President of the League of Mothers from 1975 - 79, and a member of the Wellington Women's Committee in International Women's Year in 1976, National President of the N.Z. L.O.M. from 1980-82, and as such was an Executive Member of the NCW during that time. Valerie was appointed a J.P. in 1985.

Alison Laurie was resident at the Stout Centre in 1987, researching the Parker - Hulme murder case with Julie Glamuzina. She is presently a lecturer with the Women's Studies Department at VUW. In 1990 she initiated the first course in Lesbian Studies to be held at any university in NZ.

Tessa Malcolm was a resident at the Stout Centre from Aug 1988 - May 1990 , working on a biography of Kate Sheppard who was associated with the early years of the Women's Suffrage Movement. Tessa is a descendant of Kate Sheppard. Tessa's seminar to the Stout Centre, Kate Sheppard:

The Economic Independance of Married Women was published in Women's Studies Journal, Sept, 1989.

Charlotte Macdonald was resident at the Stout Centre in 1989 as the Claude McCarthy Fellow, and has continued to work there in 1990. With a team of women researchers, she was undertaking research for The Book of New Zealand Women / Ko Kui Ma te Kaupapa, a biographical dictionary of women. She is one of three editors, the others being Bridget Williams and Merimeri Penfold. The book will be published by Allen \& Unwin. She is a historian, who specializes in the history of women in New Zealand/Aotearoa, and now lectures in the History Department at Victoria University.

Jane Malthus is a lecturer in Clothing, Textiles and Design at the University of Otago's School of Consumer and Applied Services. From June 1990 she has been a visiting researcher at the Stout Research Centre working towards her $\mathrm{PhD}$ which focuses on European women's dress in nineteenth century NZ. A paper on dress reformers appeared in the April 1989 issue of $N Z$ Journal of History and Jane is now searching for information about women who worked as dressmakers. Jane's other research interest is in anthropometry - people's size and shape - on which she has had several papers published, including One Size Does Not Fit All in the 
proceedings of the August 1989 Clothing and Textiles Symposium held in Dunedin.

Wendy Pond was a Stout Resident in 1989. She has navigated a small boat across the Pacific Ocean, published translations of Tongan poetry, edited a Tongan literary journal, worked with

Tai Tokerau elders in Northland, and reconstructed Polynesian systems of faunal classification. During her Stout residence she began work on a bicultural nature study manual.

Her short stories can be found in Islands 83, Sport 1, New Women's Fiction 1987, 1988, Good-bye to Romance, The Exploding Frangipani in press, and Storia-Antipodes in press.

Heather Roberts was at the Stout Centre in 1986 while the holder of a Claude McCarthy Fellowship. The result of her work there was Where did she come from: New Zealand Women Novelists 1864 - 1987 (Allen \& Unwin) and A Woman's Life (Penguin) co-edited with Anne Else, an anthology of writing by women about women. Both books were published in 1989. Heather has also written contributions for The Book of New Zealand Women and the Dictionary of N.Z. Biography.

Theresa Sawicka is resident at the Stout Centre 1990 - 91. She has a Claude McCarthy Fellowship to write a book based on her $\mathrm{PhD}$ thesis, Forsaken Journeys: The 'Polish' experience and identity of the 'Pahiatua Children' in New Zealand. She has a long association with Victoria University, having studied and taught in the Anthropology Department here for the past twenty years. During the rise of Solidarity, $1979-80$, she spent a year studying Polish language and history in Poland on a

UNESCO/Copernicus Scholarship. Her reflections on this were published in Embattled Poland: An Historical Reflection, Reflections on an ethnic journey. Her academic interests include Polish migration, Polish identity and the symbolic expression of that identity, the migrant experience and identity in New Zealand and the legacy of our immigrant past.
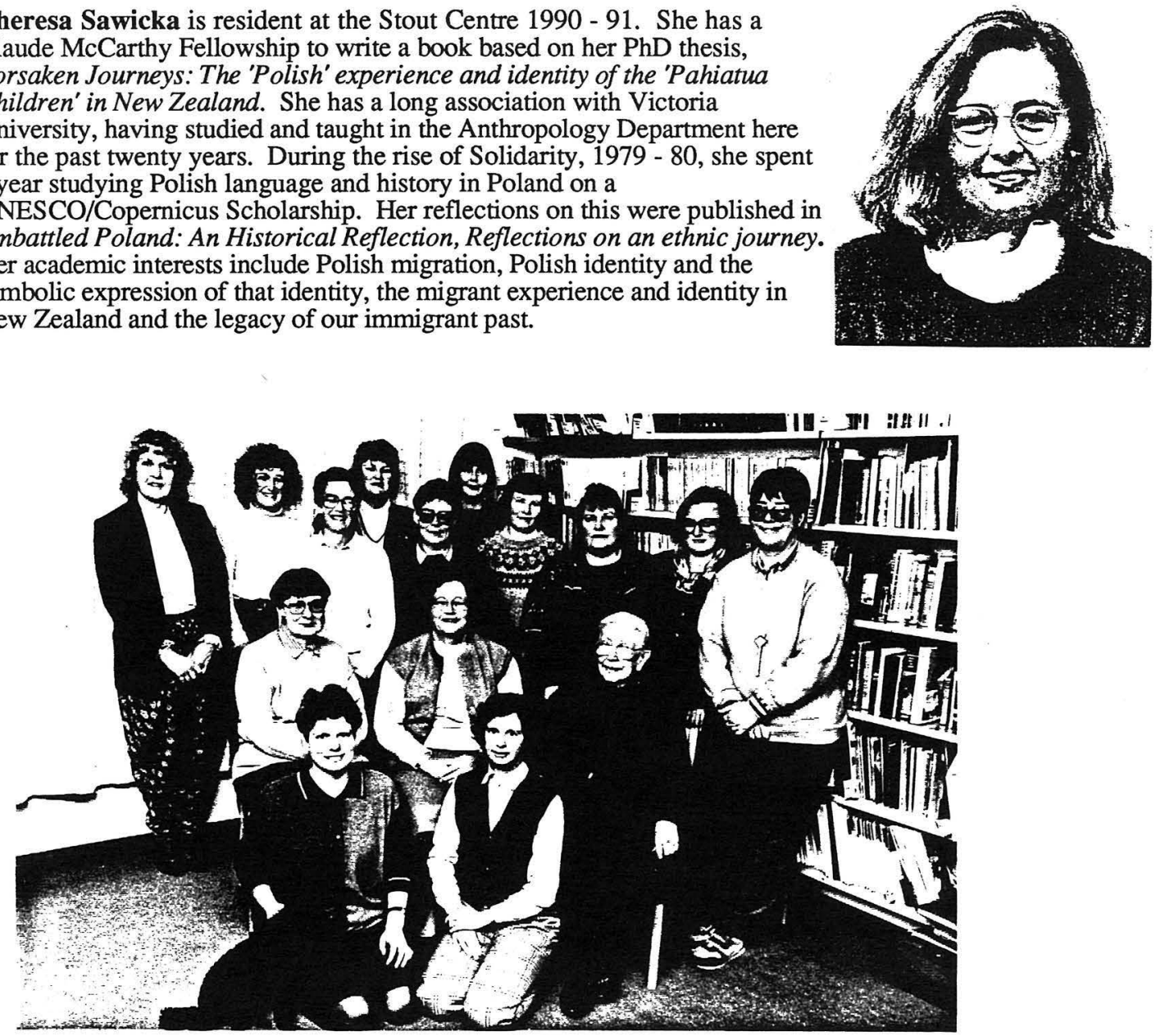

From L. to R:

Standing: Brenda Watson, Shirley Day(Gieck), Heather Roberts, Jean Harton, Alison Gray, Jane Malthus, Winifred Bauer, Adrienne Simpson, Charlotte Macdonald, Alison Laurie.

Seated: Anne Else, Valerie Jacobs, Dorothea Turner.

Floor: Jane Tolerton, Wendy Pond. PHOTO : John Casey. 
Adrienne Simpson was a Stout Resident in 1989 and 1990, and is working on topics relating to operatic and theatrical history. Major articles of hers have recently been published in $N Z$ Women's Studies Journal, Music in New Zealand and The Turnbull Record. She is the editor of Opera in New Zealand: Aspects of History and Performance which is forthcoming, and has made contributions to The New Grove Dictionary of Opera and The International Dictionary of Opera, which are also forthcoming.

Jane Tolerton, a freelance writer, came to the Stout Centre in 1987 to write a biography of Ettie Rout, the New Zealander best known for her 'safe sex' campaign among the ANZAC troops during World War One. In 1988-89 she and Nicholas Boyack, formed the WWI Oral History Archive and interviewed about 90 veterans. The tapes are now in the Alexander Turnbull Library and the resulting book, In The Shadow of War, was published by Penguin Books in April 1990. Jane is now working again on the biography which she expects to finish by the end of the year.

Dorothea Turner (b. Christchurch 1910) has written a biography, Jane Mander (Twayne, 1972), a practical monograph for New Zealand hand-spinners and weavers, Ways into Woolcraft (1978), a dissertation on Herodotus' syntax for her $\mathrm{PhD}$ (VUW, 1989), and is now working on a discontinuous memoir, Embargoed Till Midnight.

Brenda Watson became associated with Stout researchers in 1988. She is one of Wellington's most accomplished transcribers and word-processers. Her work appears in records of the Oral History Archive and in publications by Stout fellows: In the Shadow of War by Nicholas Boyack and Jane Tolerton; The Treaty Now by Bill Renwick; The Book of New Zealand Women eds Charlotte Macdonald, Merimeri Penfold \& Bridget Williams; The Matriarchs by Judith Fyfe.

\section{'Tacking Through the Gusts' : Methodology in multi-cultural and multi-disciplinary research}

WENDY POND

Resident Research Scholar at School of Biological Sciences

In this paper I chronicled my progress towards bicultural scholarship. First, I created models for fieldwork out of my own experience of growing up in this country. I allowed my research to be directed by the priorities of the society I worked in. Then I saw the harm being done by my own society and acted to counter it, establishing systematic principles of classification in Austronesian languages and giving scientific definition to Māori names of insects, to ensure their continuing use.

Then I approached Mäori knowledge from the perspective of a compatible culture: a culture with an intellectually contenious tradition, a strong poetic - metaphorical tradition, and a coherent tradition of ancient wisdom teachings.

In field work, I collaborated with New Zealand entomologists and ecologists who already have a strong sense of New Zealand scholarship, reflecting the uniqueness of the New Zealand environment.

Many scientists continue to assert the superiority of western explanations of reality, and continue to believe that their perceptions are unbiased by cultural priorities. They cannot countenance the transmission of forces between the natural and social realms, nor the transmission of knowledge through metaphore, and cannot see that dismissing Māori knowledge without investigating it, is unscientific. I noted that anthropologists and historians 